\title{
INVESTIGATION OF THE COMMUNICATION SKILL LEVELS OF SPORTS CLUB MANAGERS
}

\author{
Serap Çolak ${ }^{1}$, Rıza Erdal ${ }^{1}$, Zekiye Başaran ${ }^{1}$, Enis Çolak ${ }^{1}$, Nagehan Malkoç ${ }^{1}$, Ayla Tekin Orha², Ozan \\ Tavas $^{2}$
}

\author{
${ }^{1}$ Kocaeli University, Faculty Of Sport Sciences, Kocaeli Turkey \\ ${ }^{2}$ Kocaeli University, Faculty Of Medicine, Kocaeli Turkey
}

\section{Abstract}

When a manager is in good communication with other staff, both the staff will be happy emotionally and will bring success to the manager. Consequently, the aim of this study was to identify the communication skill levels of the sport managers with different education levels and to investigate the effect of these different educational levels on communication skills. A "Communication skills scale" was applied to 124 volunteers sport managers. The different questions on the scale reflect the mental, behavioral and emotional communication skills. It was observed that the education level of the sport managers was distributed as elementary school, secondary school, high school, undergraduate degree and graduate degree. As a result, no significant difference was found between the levels of communication skills of sport managers in relation with their age and gender $(p>0.05)$. Furthermore, the general communication skill levels according to educational status of sport managers demonstrated significant difference $(\mathrm{p}<0.05)$. University graduates are expected to increase their level of communication skills in terms of personal development owing both to their educational and pedagogical lessons and also as a result of the increasing communication with other persons.

Keywords: Communication Skills, Education, Sports Managers

\section{INTRODUCTION}

The word "communication" has been derived from a latin word "communis" which means "common" (Yilmaz, Cimen and Bektas, 2014; Colak et al., 2017). Although the word "communication" used to mean spreading the knowledge to community in XV century, but today it has become a word that expresses the conversation and transmisson of knowledge between people (Toy, 2007; Colak et al., 2017). The main feature that distinguishes human nature from other living things is that it is a social entity. Furthermore, successful managers that achieve organizational goals in mind were managers that determine guidance, control and change employee behavior (Yukl, 2008). In this way an adequate communication of sports managers is fundamental to ensure a good and productive environment for both employees and athletes. Successful communication skills and motivation of managers, as well as teamwork competencies, were the key point of positive working environment.

Human being needs mental, emotional and behavioral sensations to talk with other people, to love, to be loved, to be supported, to be supported, to be educated, to be happy and to feel sad. A person with better communication skill will better live these emotional feelings and will better assimilate them throughout his life (Colak et al., 2017). It is well known that most of the problems that people experience with other people in close in their workplaces or environment are results of inefficient communication or miscommunication (Owen and Bugay, 2014; Johnson, 1996). It is 
known that there are many factors influencing effective and healthy communication among people (Owen and Bugay, 2014). But the main thing is how these different factors will be reflected in the formation of the emotional feelings of the people. Control of known basic emotional feelings is controlled by the Limbic lobe, which is now anatomically defined as a 5th brain lobe. There are differences in Limbic lobe activities as well as differences in other human lobe activities. The emotional feelings of love, hate, happiness, love, violence and jealousy are in fact the cornerstones of human-to-human communication. Furthermore, the occurrence of a specific behavior, is dependent on certain conditions. An efficient use of behavioral science and knowledge of concepts lead to the ability to communicate correctly on the basic skills of social life (Gudarzi, Nazari \& Ehsani, 2012). Having effective and healthy communication among people is possible by means of people understanding each other correctly and reflect it to each other, treat each other with respect and with the mutual feeling of understanding (Colak et al., 2017).

Many studies indicated that people's communication skill levels are congenital and by intuition, but it is also a fact that most elements of communication are can be learned and taught
(Owen and Bugay, 2014; Buckman, 2001; Verdener, 1999; Korkut, 2005). In this context, sports managers may participate in special instructional activities at various times, to increase the level of communication skills related to their deficiencies. This educational participation will certainly contribute to managerial success. In fact, people increase their level of communication skills unintentionally during their own activities and also with the role models they encounter during their academic and social education life. Having a healthy communication with the colleagues without making any difference between the superordinate and subordinate will both make the staff happy emotionally and also bring success to the manager. The healthy and effective communication that will be made by the sport manager, athlete, coach, health team, administrative-accounting staff and other staff will bring a strong personality and social acceptance in particular to the sport manager (Fig. 1). All the staff members experience happiness and successes as a whole through the communication among them. Our study, aimed to determine the communication skill levels of sport managers with different education levels from primary school to university and investigate the effect of these different educational levels on communication skills.

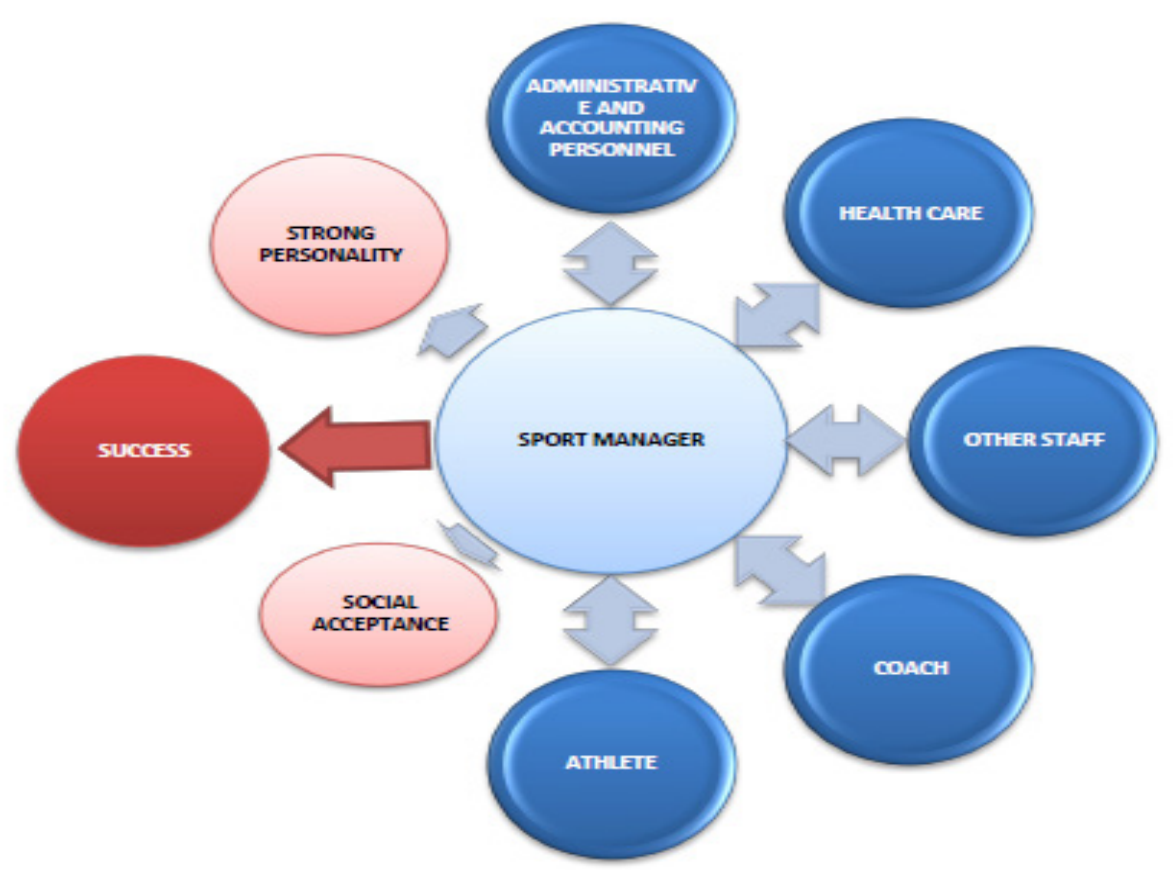

Figure 1. The healthy and effective communication that will be made by the sport manager, athlete, coach, health team, administrative-accounting staff and other staff will bring success and also this communication will bring strong personality and social acceptance to the sport manager. 


\section{METHODS}

\section{Study Group}

A total of 124 (age: 41,74 $\pm 10,53$ ) sport managers in Kocaeli participated to the study, 37 (age:35,70 $\pm 8,9$ ) females and 87 (age:44,31 $\pm 10,15)$ males. Personal Information Form (PIF) and Communication Skill Level Scale (CSLS) were applied one-to-one to voluntary managers in several sports organizations. In the questionnaire, different questions with scale value reflected the mental, behavioral and emotional aspects of the communication skills (CS) of the person. Furthermore the educational status of the sport managers participating in the study was examined (primary school, secondary school, high school, associate degree, undergraduate degree, graduate degree). The mental, behavioral, emotional and general communication skill level outcomes of the study group were evaluated statistically (SPSS 21.00) according to gender, age and educational status.

\section{Data Collection}

Personal Information Form (PIF)

The (PIF) form was distributed to sport manager in several sports organizations. The voluntary sports manager was asked to complete the form. Then, the data of the completed form including age, sex, working year and education information were separately analyzed. There was no statistically significant difference between the levels of communication skills of sport managers in terms of age, working year and gender $(\mathrm{p}>0.05)$. Descriptive statistics of communication categories according to gender was identified in the Table 1.
Communication Skill Level Scale (CSLS) In this study to determine the communication skill level of the sports managers the Communication Skill Level Scale (CSLS) developed by Ersanli and Balci (Ersanli and Balci, 1998) was used. According to the previously conducted survey, the Cronbach alpha coefficient of the reliability was 0.72 and the coefficient of the validity was 0.70. When CSLS was first used, it consisted of 70 questions. After the necessary validity and reliability studies were done, a sample consisting of 500 university students was applied. After the factor analysis the number of questions has been reduced to 45 questions of Likert type questions (expressions consists, "Always, Usually, Sometimes, Rarely, Never") (Ersanlı and Balc1, 1998; Toy, 2007). Questionnaire measures communication skills (CS) in terms of mental, emotional and behavioral. There are 15 questions measuring each dimension. The questions that enter into each dimension and the level of CS they express are as follows; Mental: 1, 3, 6, 12, 15, 17, 18, 20, 24, 28, 30, 33, 37, 43, 45, Emotional: 5, 9, $11,26,27,29,31,34$, Behavioral: consists of 2 , $4,7,8,10,13,14,16,19,21,22,23,25,32,41$ numbered questions. Higher scores in dimensions and overall correspond to higher communication skills (Toy, 2007).

\section{Analysis of data}

Statistics of the results were evaluated by SPSS 21.00 program. Descriptive statistics, two independent sample tests and variance analysis were applied for the data.

\section{RESULTS}

Table 1. Descriptive statistics and $p$ values of communication categories according to sex

\begin{tabular}{|c|c|c|c|c|c|c|c|c|c|}
\hline \multirow{2}{*}{$\begin{array}{c}\text { Communication } \\
\text { skill } \\
\text { subcategories }\end{array}$} & \multicolumn{4}{|c|}{ Female(N=37) } & \multicolumn{4}{|c|}{ Male(N=87) } & \multirow[t]{2}{*}{$\mathbf{p}$} \\
\hline & Min. & Max. & Mean & $\begin{array}{l}\text { Std. } \\
\text { Dev. }\end{array}$ & Min. & Max. & Mean & $\begin{array}{l}\text { Std. } \\
\text { Dev. }\end{array}$ & \\
\hline Total & 82.00 & 163.00 & 118.92 & 13.58 & 79.00 & 157.00 & 116.93 & 13.79 & .462 \\
\hline Mental & 29.00 & 48.00 & 38.65 & 4.37 & 24.00 & 50.00 & 38.00 & 5.23 & .509 \\
\hline Emotional & 31.00 & 54.00 & 43.27 & 5.57 & 25.00 & 55.00 & 42.20 & 5.27 & .176 \\
\hline Behavioral & 21.00 & 87.00 & 37.00 & 10.02 & 21.00 & 55.00 & 36.74 & 6.01 & .567 \\
\hline
\end{tabular}


Table 2. Table of $\mathrm{p}$ values among the communication subcategories according to educational status

\begin{tabular}{ccccccc}
\hline Educational Status & & $\mathbf{N}$ & $\mathbf{X}$ & Std.Dev. & p value & $\begin{array}{c}\text { Difference between } \\
\text { groups }\end{array}$ \\
Primary school (1) & Total & 8 & 125.88 & 9.03 & $\mathbf{. 0 5 0}$ & $1-3$ \\
& Mental & 8 & 41.75 & 4.98 & & \\
& Emotional & 8 & 42.00 & 2.27 & & $1-3$ \\
& Behavioral & 8 & 42.13 & 4.76 & $\mathbf{. 0 2 7}$ & \\
Secondary school (2) & Total & 28 & 115.68 & 14.25 & & $1-2$ \\
& Mental & 28 & 37.39 & 5.38 & $\mathbf{. 0 3 0}$ & \\
& Emotional & 28 & 42.54 & 5.49 & & \\
Associate degree (3) & Behavioral & 28 & 36.75 & 5.64 & & \\
& Total & 18 & 114.39 & 10.02 & & \\
& Mental & 18 & 38.67 & 4.06 & & \\
& Emotional & 18 & 40.61 & 4.50 & $\mathbf{. 0 5 0}$ & \\
& Behavioral & 18 & 35.11 & 4.91 & & \\
Undergraduate degree (4) & Total & 57 & 118.39 & 14.94 & & \\
& Mental & 57 & 38.05 & 5.13 & $\mathbf{. 0 5 0}$ & \\
& Emotional & 57 & 43.46 & 5.74 & & \\
& Behavioral & 57 & 36.88 & 8.97 & & \\
Graduate degree (5) & Total & 13 & 116.92 & 12.69 & & \\
& Mental & 13 & 37.69 & 4.19 & & \\
& Emotional & 13 & 43.46 & 5.30 & & \\
& Behavioral & 13 & 35.77 & 6.41 & & \\
\hline
\end{tabular}

When the subcategories of communication skill levels were compared according to the educational status of the sport managers, there was a significant difference between the behavioral communication skills of secondary school graduates and intellectual communication skills of primary school graduates and associate degrees $(\mathrm{p}<0.05)$. In addition there was a significant difference between the total communication skills of associate degrees and primary school graduates and between mental communication skills of primary school graduates and undergraduate degrees $\quad(p=0.05)$. A borderline significant difference was found between emotional communication skills of associate degrees and undergraduate degrees $(\mathrm{p}=0.05)$ (Table 2$)$.

\section{DISCUSSION AND CONCLUSION}

People who want to be together with others, to express themselves, to understand others, in short, people who want to socialize tend to communicate with others (Toy, 2007). The level of communication skills of people is the most important basis to understand, perceive, evaluate, configure relations with others and to give the right response, both sociologically and psychologically. In addition communication skill is a quality that determines ones thoughts and emotions about one's self and reactions that one will give when facing different situations and people it is also about ones perception of self as talented, important and successful (Colak et al., 2017). Also, according to Goleman, emotional intelligence provides to leader the capability to deal effectively with their own and others' emotions (Goleman, 2004). 
Toy used Personal Information Form, Communication skills inventory, Empathy skills Scale Form-B and NEO Five Factor Personality Inventory (Turkish Edition) in her study about the relationship between the faculty of engineering and law students in terms of communication skills and the relationship between communication skills and some variables on 410 students as a measuring tool. We also used the Communication Skills Scale in our study. The same researcher stated that in terms of communication skills, law students are better than engineering students, and females are better than males. When the effect of personal traits are controlled, law students stayed better in communications skills but the differences between genders has disappeared (Toy, 2007). In our study, there was no significant difference between Communication skill levels in terms of gender ( $p>0.05)$ (Table 1). A similar study has mentioned that there was no significant difference between gender and communication skills but there was a significant difference between sports departments and communication skills (Akdagcik and Mamak, 2016). Whereas different studies have defined that men's communications skills were more effective than women's (Nazari, Emami, and Yektayar, 2013; Nazari and Nurbakhshian, 2016). It can estimated that men used more verbal communication and while women, who are more sentimental, use non-verbal communication.

Some researchers have attempted to reveal the relationships and differences between the concepts of knowledge, behavior and communication in order to provide a better understanding of interpersonal communication skills (Burgoon, Buller, \& Woodall, 1989). According to the authors, knowledge is a top concept which includes notion of behavior and communication. According to these authors, all kinds of stimuli originating from the surroundings and reducing the uncertainty for the organism should be considered as knowledge. Therefore, knowledge is the source of all kinds of communication that will enable the individual to be involved in the interpretation of the environment and to direct his / her behavior. It can be deduced that a good communication is primordial to form the basis of knowledge. A good manager also increases his knowledge throughout his/her social and educational life through communication with people. Good communication means much knowledge and therefore success for managers. However, according to the result of this study, in terms of graduation levels, only significant difference was found between total and behavioral communication skill levels of primary school graduates and associate degree sports managers $(p<0.05)$. In this context, when we distinguished two groups as pre-university (primary school, secondary school, high school) and postuniversity (Associate, Undergraduate), it differed in the transition period to university while there was no difference between the groups' general communication skill levels. The Associate Degree is the first stage of university education and it is a place where people carry their education level to the next level. It is expected that the level of communication skills will increase in terms of personal development due to the education and pedagogical lessons that they took in university and the increase in the communication with others. Moreover, there was a significant difference between elementary school and secondary school graduates in terms of mental communication skill levels $(p<0.05)$ (Table 2$)$. This suggests that in the transition phase of middle school, children leave mental communication skills with the effect of hormonal changes due to the onset of puberty and gravitate towards to emotional communication skills. Close to our study, Nazari et al. have determined in their study that 85 percent of managers have a bachelor's degree, 14 percent have master's degree and only 1 percent of managers are $\mathrm{PhD}$ and they defined that managers who have higher education have higher effective communication skill in administration. They determined that more experience and more effective social relationship between manager and employees supply the good communication skill. Sports managers with a good dialogue and a good feedback (Nazari et al., 2011; Yukl, 2008)

Development of basic knowledge, understanding the environment and establishing effective communication with all colleagues were indispensable to achieve goals in all sports organisation at each management level.

\section{REFERENCES}

Akdağcık, U. and Mamak, U. (2016) The effect of communication skills on team and individual sports. Turk J Sport Exe 18(3): 73-77.

Buckman, R. (2001) Communication skills in palliative care. Neurologic Clinics 19(4):9.

Burgoon, J.K., Buller, D.B. \& Woodall, W.G. (1989)

Nonverbal communication: the unspoken dialoge. 
New York: Harper \& Row.

Çolak, S., Başaran, Z., Erdal, R., Demirkiran, G. (2017) Effect on Communication Skill Levels of Regulatory Recreative Activities in Children. 9.International Physical Education Teachers and Sports Instructors Congress. Antalya, Turkey, 19-22.

Goleman, D. (2004) What makes a leader? Harvard Business Review, The best of HBR edition, January.

Gudarzi, M., Nazari, R., \& Ehsani, M. (2012) Structural Equation Model of the Impact of the Communication Skills on the Management Skills of Sports Managers. Applied Research of Management and Biological Science in Sport (1):11-20.

Ersanli, K. \& Balci, S. (1998) Iletisim Becerileri Envanterinin Gelistirilmesi: Gecerlik ve Guvenirlik Calismasi, Turk Psikolojik Danısma ve Rehberlik Dergisi 10(2):7-12

Johnson, D. W. (1996) Reaching out: Interpersonal effectiveness and self-actualization, 6th ed. Boston, Allyn \& Bacon.

Korkut, F. (2005) Yetiskinlere yönelik iletisim becerileri egitimi, Hacettepe Üniversitesi Egitim Fakültesi Dergisi (28):143-149.

Nazari, R., Ehsani, M., Ghangoei, F.A., Ghasemi, H. (2011) The Effects of Communication Skills and Interpersonal Communication on Organizational Effectiveness of Iranian Sport Managers and Presenting a Model. Middle-East J Sci Res 10(6): 702-710.

Nazari, N., Emami, F., and Yektayar M.(2013) Structural equations modeling of the effect communication skills onmanagerial skills and its role on organizational culture in sport organization. European Journal of Experimental Biology 3(3):184-189.

Nazari, R. and Nurbakhshian, A. (2016) The Analysis of the Relationship between Communication Skills and the Establishment of Clark's Management Network among Sport Managers. Int J SCS 4(1):14-22.

Owen, FK., Bugay, A. (2014) Developing a Communication Skills Scale: Validity and Reliability Studies. Mersin University Journal of the Faculty of Education 10(2):51- 64.

Toy, S. (2007) Muhendislik ve Hukuk Fakulteleri Öğrencilerinin İletisim Becerileri Açısından Karsılaştırılması ve İletisim Becerileriyle Bazı Degişkenler Arasındaki İliskiler. Yüksek Lisans Tezi, Anakara Üniversitesi, Ankara.

Verdener, R. F. (1999) Communicate! (9th Ed). Belmont CA: Wadsworth Publishing Company.

Y1lmaz, I., Cimen, Z. ve Bektas, F. (2010) Sporcu algilamalarina gore bireysel ve takim sporu antrenorlerinin iletisim beceri düzeylerinin karşılastırılması. Beden Egitimi ve Spor Bilimleri Dergisi 11(4) 52-57.
Yukl, G. (2008) How leaders influence organizational effectiveness. The Leadership Quarterly 19(6):708722 . 